\title{
A synthetic approach to bacteriochlorin derivatives using natural chlorophyll a pigment
}

\author{
Luna S. dos Santos, Thais C. dos Santos, Timothy J. Brocksom and
}

Kleber T. de Oliveira *

Departamento de Química, Universidade Federal de São Carlos - UFSCar, Rodovia Washington Luiz km 235, São Carlos-SP, 13565-905, Brazil.

*kleber.oliveira@ufscar.br

Keywords: organic synthesis, bacteriochlorin, Photodynamic Therapy

\section{INTRODUCTION}

Bacteriochlorin derivatives are tetrapyrrolic macrocycles that differ from porphyrins and chlorins only in the reduced state of the $\beta$-pyrrolic positions. These differences are sufficient to modify the electronic spectra of the bacteriochlorins, obtaining an adequate Q-band $>730 \mathrm{~nm}$ compared to porphyrins (last Q-band around $630 \mathrm{~nm}$ ) and chlorins (last Q-band around $650 \mathrm{~nm}$ ). ${ }^{1}$ Compounds with absorption bands greater than $700 \mathrm{~nm}$ have been suggested as better photosensitizers to be applied in photodynamic therapy (PDT) treatments, since they have strong absorption of penetrating light $(>700 \mathrm{~nm})$. PDT is a very innovative technique for the treatment of skin cancer, several malignant tumors, viral, bacterial and dermatological diseases. In this work, we present studies on the extraction and synthesis of new photosensitizers based on natural models such as chlorophyll a (1) (Scheme 1).

\section{RESULTS AND DISCUSSION}

The pigment 1 was extracted from algae Spirulina maxima using a $5 \%$ solution of $\mathrm{H}_{2} \mathrm{SO}_{4}$ in $\mathrm{MeOH}$ and converted to methyl-pheophorbide (2) in one step (12h). After basic quenching and purification by silica gel, the pigment 2 was obtained with high purity in $0.5 \%$ yield. ${ }^{2,3}$ Compound 2 was converted to 3 using stoichiometric quantities of $\mathrm{MeONa}$ in $\mathrm{MeOH}$ (retro-Dieckmann reaction) at $0^{\circ} \mathrm{C} \rightarrow \mathrm{rt}$. The pigment 3 was obtained in $77 \%$ yield after purification by silica gel. Then, compound 3 was hydrogenated $\left(\mathrm{H}_{2} / \mathrm{Pd}\right.$, 1atm, 4h) furnishing 4 after simple filtration on celite $\left(80 \%\right.$ yield). ${ }^{4}$ Now, we are starting the studies using compound $\mathbf{4}$ as dipole in a 1,3 dipolar cycloaddition with the azomethine ylide of 5. According to recent literature about chlorophyll derivatives, the opposite double bond (compound $\mathbf{4}$, highlighted in red - scheme 1) is well activated for regioselective additions.

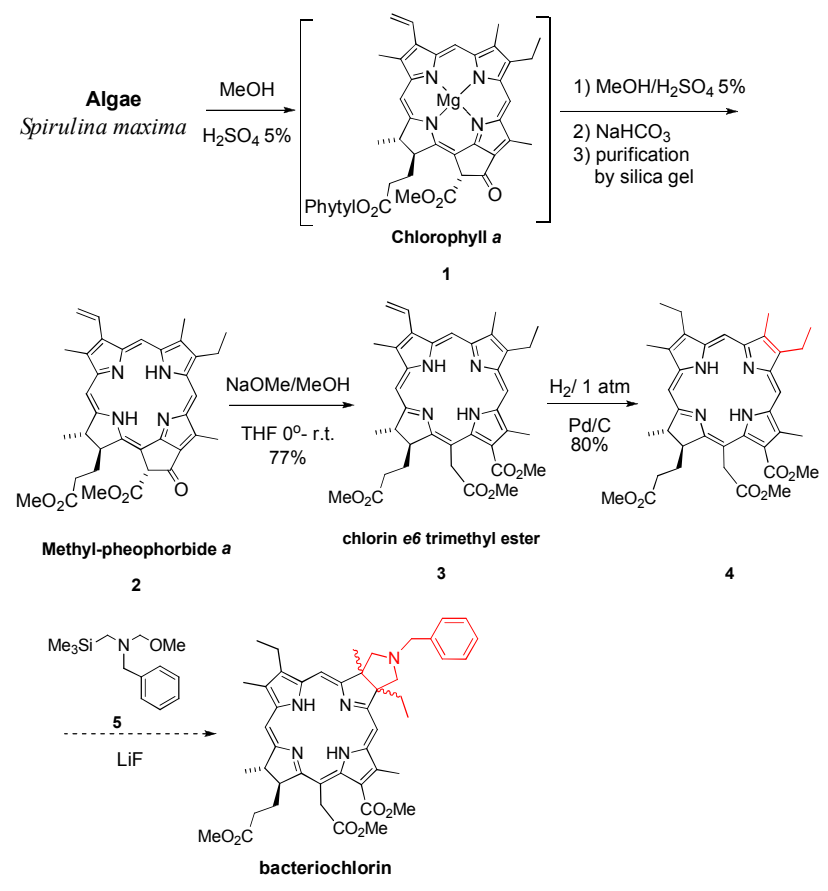

Scheme 1. Synthesis of bacteriochlorins.

\section{CONCLUSION}

Extraction and synthetic transformations of chlorophyll a (1) are described. Compound 4 was successfully prepared, and the 1,3-dipolar cycloaddition will be studied.

\section{ACKNOWLEDGEMENTS}

The authors thank FAPESP (2008/06619-4), CNPq (470338/2010-5) and CAPES for financial support. Thanks are also due to CNPq for scholarship of Luna S. dos Santos.

\section{REFERENCES}

${ }^{1}$ Ruzié, C.; Krayer, M.; Balasubramanian, T.; Lindsey, J. S. J. Org. Chem. 2008, 73, 5806 .

Hargus, J. A.; Fronczek, F. R.; Vicente, M. G. H.; Smith, K. M. Photochem. Photobiol. 2007, 83, 1006.

${ }^{3}$ Maestrin, A. P. J.; Neri, C. R.; de Oliveira, K. T.; Serra, O. A.; lamamoto,

Y. Quim. Nova 2009, 32, 1670.

${ }^{4}$ Gerlach, B.; Brantley, S. E.; Smith, K. M. J. Org. Chem. 1998, 63, 2314. 